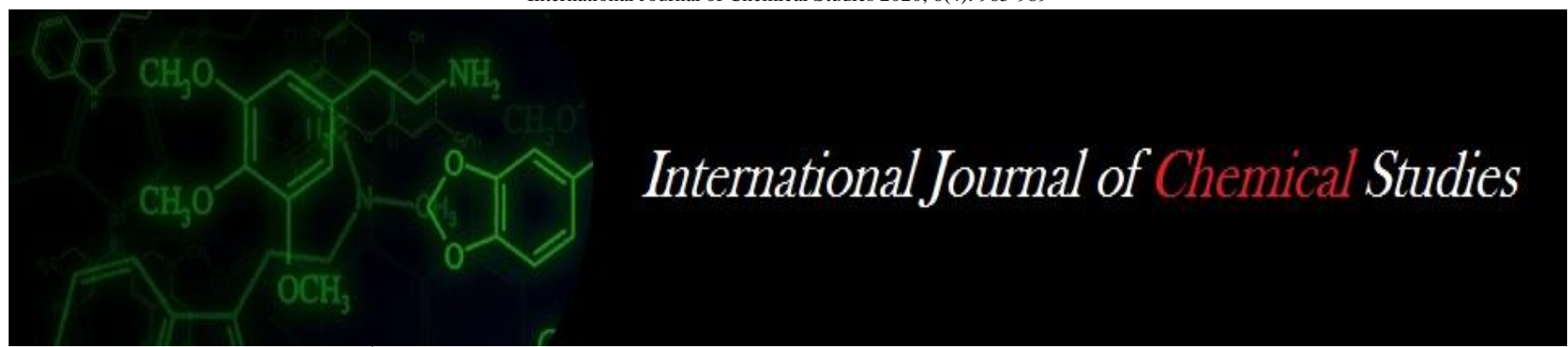

P-ISSN: 2349-8528

E-ISSN: 2321-4902

www.chemijournal.com

IJCS 2020; 8(4): 983-989

(C) 2020 IJCS

Received: 19-05-2020

Accepted: 21-06-2020

Rajendiran Selladurai

ICAR-Indian Institute of Soil

Science, Nabibagh, Berasia

Road, Bhopal, Madhya Pradesh,

India

Mohanlal Dotaniya

ICAR-Indian Institute of Soil

Science, Nabibagh, Berasia

Road, Bhopal, Madhya Pradesh,

India

Vassanda Coumar Mounisamy ICAR-Indian Institute of Soil Science, Nabibagh, Berasia

Road, Bhopal, Madhya Pradesh, India

Nishant Kumar Sinha

ICAR-Indian Institute of Soil

Science, Nabibagh, Berasia

Road, Bhopal, Madhya Pradesh,

India

Vinay Kumar Singh

Krishi Vigyan Kendra (KVK),

Rajgad Naka, Jhabua, Madhya

Pradesh, India

Sandeep Somil Chauhan

Krishi Vigyan Kendra (KVK),

Mandu Link Road, Dhar,

Madhya Pradesh, India

Awadhesh Kumar Tripathi ICAR-Indian Institute of Soil

Science, Nabibagh, Berasia

Road, Bhopal, Madhya Pradesh, India

Samaresh Kundu

ICAR-Indian Institute of Soil

Science, Nabibagh, Berasia

Road, Bhopal, Madhya Pradesh, India

Corresponding Author: Rajendiran Selladurai

ICAR-Indian Institute of Soil

Science, Nabibagh, Berasia

Road, Bhopal, Madhya Pradesh, India

\section{Sustainable soil quality management for enhancing crop productivity in tribal areas of central India: A case study}

\author{
Rajendiran Selladurai, Mohanlal Dotaniya, Vassanda Coumar \\ Mounisamy, Nishant Kumar Sinha, Vinay Kumar Singh, Sandeep Somil \\ Chauhan, Awadhesh Kumar Tripathi and Samaresh Kundu
}

DOI: https://doi.org/10.22271/chemi.2020.v8.i4g.9730

\begin{abstract}
The objectives of current investigation are to assess soil quality and sustainable management of soils for enhancing crop productivity in the tribal districts (Jhabua, Alirajpur and Dhar) of central India. Field trials were conducted in ten farmers' fields for two years. Soybean-wheat system was adopted in six farmers' fields and maize-wheat system in four farmers' fields. Treatments were integrated plant nutrient supply (IPNS); soil test based nutrient management (STNM); recommended doses of fertilizers (RDF) and farmers' practices (FP). Initial and post experiment soil samples were collected and analyzed. Soil quality changes were also studied. IPNS and STNM practices improved crop yield, farm income and soil quality compared to RDF and FP. Low organic carbon and deficiency of N, S and P are the major soil constraints in the region. Therefore, IPNS and STNM could be practiced to enhance crop productivity, farm income and to maintain soil health in the region.
\end{abstract}

Keywords: Crop yield, soil management, soil quality index, soil properties, tribal area

\section{Introduction}

Soil, together with water and air, constitute the most important natural resource. It is essential to use these resources wisely for sustainable development and feeding the growing world population [2]. Protection of soil quality under intensive land use and fast economic development is a major challenge for sustainable resource use in the developing world ${ }^{[5]}$. In the past decades, a significant decline in soil quality has occurred worldwide due to adverse side effects of different human activities and contamination by inorganic and organic chemicals used in agriculture and industry ${ }^{[25]}$. Intensification of agriculture is widely recognized as one of the most significant alterations to the global environment by humans. Concerns have developed, however, over the long-term sustainability and environmental consequences of intensifying agricultural production. In Asia, adverse effects on soil quality arise from soil erosion, loss of organic matter, localized nutrient depletion or excessive fertilization, soil pollution ${ }^{[12]}$. There is a need for greater as well as more reliable agricultural yield to feed the growing population. It can only be achieved when quality of soil is good enough to produce sufficient food. Interest in soil quality is increasing throughout the world as humankind recognizes the fragility of earth's soil, water, and air resources and the need to protect them for sustained agricultural production.

A better long-range, landscape-scale planning and land-use can be possible by addressing the integrated concept of soil quality. Accurate and consistent assessment of soil quality requires a systematic method for measuring and interpreting soil properties that adequately serve as soil quality indicators ${ }^{[9]}$. It is very well known that an individual soil property may not be an adequate measure of soil quality. Integrated soil quality indicators based on a combination of soil properties could better reflect the status of soil quality than individual parameters ${ }^{[3,7]}$. Soil quality defined as the capacity of specific kind of soil to function, within natural or managed ecosystem boundaries, to sustain plant and animal productivity, maintain or enhance water and air quality, and support human health and habitation ${ }^{[4,6,15]}$. Soil quality assessment is a tool focus on dynamic soil properties and processes which are useful for assessing the 
sustainability of soil management practices. Further assessment of soil quality is necessary to evaluate the degradation status and changing trends following different land use and smallholder management interventions ${ }^{[17]}$.

Sustainable agriculture should involve the successful management of agricultural resources to satisfy changing human needs while maintaining or enhancing the natural resource base, and avoiding environmental degradation. Sustainable agriculture encompasses, but is not limited to, farming systems which are biological, ecologically clean, low-input, organic, and alternative agriculture. These systems emphasize the sustainability of the soil resource that is, along with the other essential resources of water, air, and light, sustaining our food production ${ }^{[11]}$. Thus, a major concern for sustainable societies should be the impact of soil management practices on the physical, chemical, and biological processes of soils that influence the sustainability of agriculture. The scientific basis of that integration, and the economic and social costs of all such practices that enhance soil quality, must be better understood and incorporated into the development of practices that can be widely implemented. Important questions concerning the definition and remediation of soil quality still need to be addressed. Developing the knowledge to define a healthy or high quality soil and what are the acceptable ranges of soil quality resulting from agricultural practices will require intensive research. Impact of specific farming practices and farming systems on soil properties and soil quality under various climatic conditions needs major attention. Additionally, the possibilities for crop yield improvement in low soil quality areas following soil quality remediation practices need to be investigated. Keeping all the above in mind, the investigation on assessment and sustainable management of soil quality for enhancing crop productivity in tribal areas of Madhya Pradesh has been undertaken to improve soil quality and maintain sustainable crop production for longer period by introducing improved management practices to enhance livelihood status of the tribal farmers.

\section{Materials and Methods \\ Study area}

Tribal dominated economically most backward districts of Madhya Pradesh state in the central India namely Alirajpur, Jhabua and Dhar districts were selected for the study. This region lies in the western part of Madhya Pradesh and comes under Central Plateau and Hills Agro-Climatic Region [1, 16] and Madhya Bharat plateau, western Malwa Plateau, eastern Gujarat plain Vindhya Satpura range and Narmada valley Agro-Ecological Region ${ }^{[8]}$. It is surrounded by Panchmahal and Baroda districts of Gujarat, Banswara district of Rajasthan, and Indore, Badwani, West Nimar, Ujjain and Ratlam districts of Madhya Pradesh. These districts are a tribal dominated about more than $80 \%$ of the total population in case of Alirajpur and Jhabua and more than $60 \%$ of total population in Dhar district. Almost half of the population lives below the poverty line. The Bhil and Bhilala are the major tribal peoples inhabit in these districts. This region comprises highly drought-prone and degraded waste lands. Major problems associated in the region are failure of rainfall and low water availability, severe land degradation and soil erosion, undulating topography, shallow soil, low soil water retention capacity, fluoride contamination in ground water, poor crop productivity, single crop per year and monocropping, low soil fertility, landless labours or marginal land holdings, agricultural indebtedness, migration, etc. Most of the rural population in these areas are depends on agriculture for their livelihood. The major crops grown in these districts are maize (both in kharif and rabi season), soybean, cotton, and black gram in kharif; wheat and gram in rabi. Some of the minor crops are urd, groundnut, peas, sorghum, pigeon pea, chillies, garlic, potato, onion, tomato, and paddy. The soils are grouped under Entisols and more than $80 \%$ of the soils are shallow to medium deep soils ${ }^{[31]}$.

\section{Field experiment}

Field trials were carried out in ten farmers' fields at five selected villages of Jhabua (Chotaguda and Bhaglawat), Alirajpur (Rodudah and Bawdi Kurd) and Dhar (Dilawra) districts to compare the different management interventions for enhancing of crop productivity and income of the farmers as well as soil quality. For that initial and final soil samples were collected from ten experimental fields and were analyzed. Soil quality was also assessed.

\section{Experimental details}

There were four treatment modules used and were farmers practices (FP), recommended doses of fertilizers (RDF), integrated plant nutrient supply (IPNS) $(75 \%$ RDF + FYM, 2 t $\mathrm{ha}^{-1}$ ), and soil test based nutrient management (STNM). The plot size was kept as $10 \mathrm{~m}$ length and $10 \mathrm{~m}$ width $\left(100 \mathrm{~m}^{2}\right)$ for each treatment. Crops raised were soybean variety JS 9560 (in 6 farmers' field) and maize hybrid PEHM 2 (in 4 farmers' field) in kharif (rainy) season and wheat variety GW 322 (in all the farmers' fields) in rabi (winter) season. These experiments were carried out in two consecutive years from 2014-15 and 2015-16.

\section{Description of the treatment}

Generally farmers in these districts use only DAP at the time of sowing and small amount of urea for top dressing to maize and wheat. The average fertilizer consumption of these areas was only $26 \mathrm{~kg} \mathrm{ha}^{-1}$. Considering the above fact, in the FP about $50 \%$ RDs of $\mathrm{N}$ and $\mathrm{P}$ were applied. In RDF treatment recommended dose of fertilizers were applied through diammonium phosphate (DAP), urea and muriate of potash (MOP). The recommended doses of fertilizers were $20 \mathrm{~kg} \mathrm{~N}$, $60 \mathrm{~kg} \mathrm{P}_{2} \mathrm{O}_{5}$ and $40 \mathrm{~kg} \mathrm{~K}_{2} \mathrm{O}$ ha $^{-1}$ for soybean and $120 \mathrm{~kg} \mathrm{~N}, 60$ $\mathrm{kg} \mathrm{P}_{2} \mathrm{O}_{5}$ and $40 \mathrm{~kg} \mathrm{~K}_{2} \mathrm{O}$ per ha- ${ }^{-1}$ for wheat and maize. In case of IPNS $75 \%$ of RDFs through inorganic fertilizers mentioned above and $2 \mathrm{t}$ FYM ha ${ }^{-1}$ to each crop before 15 days of sowing were applied. Whereas in STNM treatments, based on the soil test values of each field fertilizers were applied, if soil test value fell in medium category, then $100 \%$ RDF was practiced and if it were low, $25 \%$ extra nutrients was supplied over RDF and if it were high, $25 \%$ lesser nutrients were supplied than RDF. In STNM treatment, single super phosphate (SSP) was used as $\mathrm{P}$ source instead of DAP because all the soils were deficient in available $S$, hence, to meet the $S$ requirement of crops as well as to avoid more expenses. In RDF, IPNS and STNM, all the fertilizers were applied as basal dose for soybean, whereas in maize and wheat all $\mathrm{P}$ and $\mathrm{K}$, and $50 \%$ of $\mathrm{N}$ were applied as basal dose and the remaining $\mathrm{N}$ was applied in two equal splits as top dressing at 30 and 60 DAS. During kharif crops were grown in rain-fed conditions and for wheat total 3-4 irrigations were given. Pre-emergence herbicides were used to control the weeds and one hand weeding was done after 45 days. At maturity crops were harvested and seed/grain yield was recorded. At the end of the experiment soil samples were collected in each field and soil quality status was determined. 


\section{Soil sampling and analysis}

Representative surface soil samples $(0-15 \mathrm{~cm}$ depth) in the experimental fields before and after the experiment in all the treatment plots were collected. In each plot, soil samples collected from 6 places, mixed thoroughly and compartmenting and quartering method reduced to half $\mathrm{kg}$ to get representative sample. Collected soils were air dried, processed, passed through $2 \mathrm{~mm}$ sieve and stored. Soil organic carbon ${ }^{[32]}, \mathrm{pH}^{[14]}$, mineralizable $\mathrm{N}^{[29]}$, Olsen $\mathrm{P}^{[22]}$, available $\mathrm{K}^{[10]}$, available $\mathrm{S}^{[34]}$, DTPA extractable $\mathrm{Zn}, \mathrm{Fe}, \mathrm{Mn}$ and $\mathrm{Cu}^{[19]}$ were analysed following the standard procedures.

\section{Soil quality assessment}

Expert opinion method was adopted for soil quality assessment. Each of the indicators was divided into four classes namely, Class - I, Class - II, Class - III and Class - IV with an assigned score of 4, 3,2 and 1, respectively and weights (Table 1).

Table 1: Soil quality indicators and their weights and classes for the evaluation of soil quality

\begin{tabular}{|c|c|c|c|c|c|}
\hline Soil quality indicators & Weight & Class I & Class II & Class III & Class IV \\
\hline Organic carbon $(\mathrm{OC}, \%)$ & 25 & $>1$ & $1-0.75$ & $0.75-0.5$ & $<0.5$ \\
\hline Soil pH & 10 & $6.5-7.5$ & $6.5-6 / 7.5-8$ & $6-5.5 / 8-8.5$ & $<5.5 />8.5$ \\
Mineralizable N $\left(\mathrm{kg} \mathrm{ha}^{-1}\right)$ & 15 & $>560$ & $560-420$ & $420-280$ & $<280$ \\
Olsen P $\left(\mathrm{kg} \mathrm{ha}^{-1}\right)$ & 10 & $>25$ & $15-25$ & $15-10$ & $<10$ \\
Available K $\left(\mathrm{kg} \mathrm{ha}^{-1}\right)$ & 10 & $>280$ & $280-200$ & $200-120$ & $<120$ \\
Available S $\left(\mathrm{mg} \mathrm{kg}^{-1}\right)$ & 10 & $>25$ & $25-15$ & $15-10$ & $<10$ \\
DTPA- Zn $\left(\mathrm{mg} \mathrm{kg}^{-1}\right)$ & 5 & $>2.0$ & $2.0-1.0$ & $1.0-0.5$ & $<0.5$ \\
DTPA- Fe $\left(\mathrm{mg} \mathrm{kg}^{-1}\right)$ & 5 & $>10.0$ & $10-5.5$ & $5.5-2.5$ & $<2.5$ \\
DTPA-Mn $\left(\mathrm{mg} \mathrm{kg}^{-1}\right)$ & 5 & $>10.0$ & $10.0-4.0$ & $4.0-2.0$ & $<2.0$ \\
DTPA-Cu $\left(\mathrm{mg} \mathrm{kg}^{-1}\right)$ & 5 & $>2.0$ & $2.0-0.5$ & $0.5-0.2$ & $<0.2$ \\
\hline Score & - & 4 & 3 & 2 & 1 \\
\hline
\end{tabular}

The soil quality index (SQI) was calculated by the following equation given by Wang and Gong ${ }^{[33]}$.

$\mathrm{SQI}=\sum\left(\mathrm{W}_{\mathrm{i}} \times \mathrm{I}_{\mathrm{i}}\right)$

Where, Wi was the weight of the indicator and Ii was the marks/score of the indicator class. Thus, summing up of all the 15 indicators provided the SQI value for a particular soil of the farmer's field. In order to judge the SQI value of any site against the theoretical maximum value of SQI (i.e. 400), the concept of relative soil quality index (RSQI) was used. The RSQI was calculated as below:

$\mathrm{RSQI}=\frac{\mathrm{SQI}_{\text {sample }}}{\mathrm{SQI}_{\max }} \times 100$

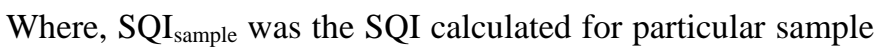
using Eq. (1) and $\mathrm{SQI}_{\max }$ was the maximum SQI value.

\section{Economics}

The economic (net gain in Rs.) was calculated from the average yield obtained and fertilizers/manures consumed. The cost of fertilizers were kept as urea Rs. 6/kg, SSP Rs. 6.5/kg, DAP Rs. $22 / \mathrm{kg}$, MOP Rs. $17 / \mathrm{kg}$ and FYM Rs. $500 \mathrm{t}^{-1}$. Further the prices of soybean Rs. $30 \mathrm{~kg}^{-1}$; wheat Rs. $18 \mathrm{~kg}^{-1}$; and maize Rs. $15 \mathrm{~kg}^{-1}$. As all the management practices were common except fertilizers and manures in all the treatments, excess cost incurred and excess income generated in each treatment when compared to farmers practice was calculated from these data. The difference in these two values was considered as net gain.

\section{Results \\ Effect on crop yield}

The average grain/seed yield of soybean, maize and wheat obtained under various treatments during kharif and rabi of 2014-15 and 2015-16 were presented in Table 2. It was observed that average soybean yield in FP, RDF, IPNS and STNM across the farmers' fields ranged from 11.76-14.61, 12.48-15.33, 12.39-15.43 and 12.85-15.58 kg plot $^{-1}$, respectively. Similarly the corresponding values were 15.23 21.26, 16.32-23.12, 16.46-23.26 and 17.09-23.99 $\mathrm{kg} \mathrm{plot}^{-1}$ for maize; $21.75-26.95,23.5-28.9,23.25-29.00$ and 24.55-30.10 $\mathrm{kg} \mathrm{plot}^{-1}$ for wheat, respectively. Across the farmers field two years mean yield under FP, RDF, IPNS and STNM were 13.30, 14.10, 14.28 and $14.52 \mathrm{~kg} \mathrm{plot}^{-1}$ for soybean; 18.10, 19.48, 19.51 and $20.17 \mathrm{~kg} \mathrm{plot}^{-1}$ for maize; and 24.15, 25.74, 25.88 and $27.09 \mathrm{~kg}$ plot $^{-1}$ for wheat, respectively (Table 2). The percent increase in crop yields under RDF, IPNS and STNM over farmers practices were $5.97 \%, 7.20 \%$ and $9.170 \%$ for soybean; $7.60 \%, 7.74 \%$ and $11.4 \%$ for maize; and $6.6 \%, 7.20 \%$ and $12.2 \%$ for wheat respectively (Fig 1). The response was more in maize followed by wheat and soybean to nutrient applications.

Table 2: Mean soybean, maize and wheat yields of two years (2014-15 and 2015-16)

\begin{tabular}{|c|c|c|c|c|c|c|c|c|}
\hline \multirow[t]{2}{*}{ Village } & \multicolumn{2}{|c|}{ FP $\left(\mathrm{kg} \mathrm{plot}^{-1}\right)$} & \multicolumn{2}{|c|}{ RDF (kg plot $\left.{ }^{-1}\right)$} & \multicolumn{2}{|c|}{ IPNS (kg plot $\left.{ }^{-1}\right)$} & \multicolumn{2}{|c|}{ STNM $\left(\mathrm{kg} \mathrm{plot}^{-1}\right)$} \\
\hline & Soybean & Wheat & Soybean & Wheat & Soybean & Wheat & Soybean & Wheat \\
\hline Chotaguda & 14.1 & 26.1 & 14.9 & 28.4 & 15.2 & 28.4 & 15.6 & 29.8 \\
\hline Dilawra & 13.3 & 22.2 & 14.2 & 24.0 & 14.6 & 24.2 & 14.8 & 25.8 \\
\hline Bawdi Kurd & 11.8 & 21.9 & 12.5 & 23.1 & 12.6 & 23.3 & 12.9 & 24.6 \\
\hline Bhaglawat & 12.7 & 21.8 & 13.7 & 23.4 & 13.7 & 23.4 & 14.0 & 24.6 \\
\hline Dilawra & 14.6 & 26.2 & 15.3 & 27.6 & 15.4 & 28.0 & 15.6 & 29.1 \\
\hline Rodudah & 13.3 & 21.9 & 14.0 & 23.1 & 14.1 & 23.3 & 14.4 & 24.4 \\
\hline Mean & 13.3 & - & 14.1 & - & 14.3 & - & 14.5 & - \\
\hline & Maize & Wheat & Maize & Wheat & Maize & Wheat & Maize & Wheat \\
\hline Chotaguda & 21.3 & 27.0 & 23.1 & 28.6 & 23.3 & 29.0 & 24.0 & 30.0 \\
\hline Bhaglawat & 16.7 & 24.1 & 18.2 & 25.2 & 18.0 & 25.5 & 18.6 & 26.3 \\
\hline
\end{tabular}




\begin{tabular}{|c|c|c|c|c|c|c|c|c|}
\hline Bawdi Kurd & 15.2 & 23.7 & 16.3 & 25.4 & 16.5 & 25.3 & 17.1 & 26.5 \\
\hline Rodudah & 19.2 & 26.9 & 20.3 & 28.9 & 20.3 & 28.6 & 21.0 & 30.1 \\
\hline Mean & 18.1 & 24.2 & 19.5 & 25.7 & 19.5 & 25.9 & 20.2 & 27.1 \\
\hline
\end{tabular}

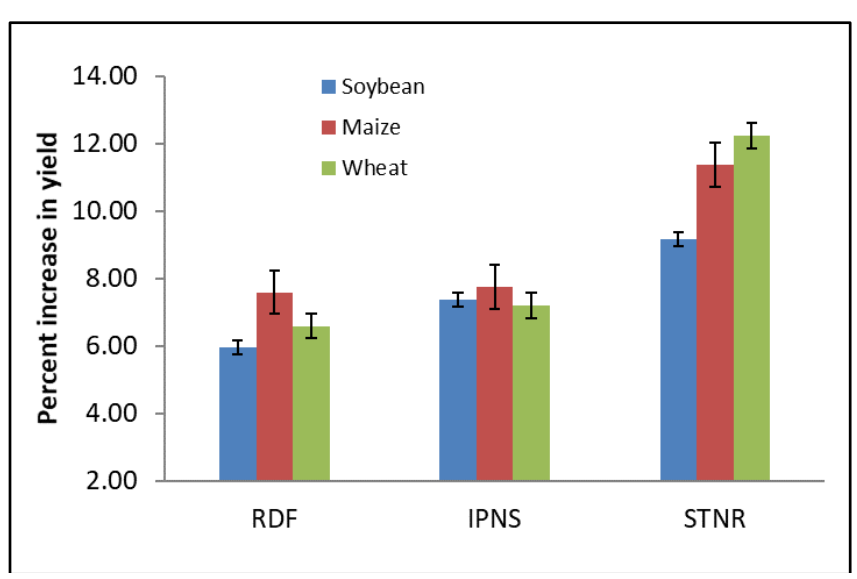

Fig 1: Percent mean yield increase under different management practices over farmers' practices

\section{Influence on soil properties}

After two years of experiment, there was significant improvement in SOC (from 0.61-0.68\%), mineralizable-N (from 242-261 kg ha-1) Olsen P (from 9.71-13.6 kg ha-1) and available S (7.09-8.2 $\mathrm{mg} \mathrm{kg}^{-1}$ ) to STNM and IPNS practices. Practice of RDF maintained these soil properties, whereas FP caused the significant reduction in available $\mathrm{K}$ and slight reduction in $\mathrm{OC}, \mathrm{N}$, and $\mathrm{S}$. As soils were already sufficient in all the micronutrients, there were no significant changes observed (Table 3 ).

Table 3: Change in soil properties under different management practices

\begin{tabular}{|c|c|c|c|c|c|}
\hline Soil Properties & Initial & FP & RDF & IPNS & STNM \\
\hline $\mathrm{pH}$ & 6.96 & 7.12 & 7.17 & 6.90 & 7.29 \\
\hline Organic carbon $(\mathrm{OC}, \%)$ & 0.61 & 0.58 & 0.62 & 0.68 & 0.66 \\
\hline Mineralizable N $\left(\mathrm{kg} \mathrm{ha}^{-1}\right)$ & 242 & 232 & 245 & 257 & 261 \\
\hline Olsen P $\left(\mathrm{kg} \mathrm{ha}^{-1}\right)$ & 9.71 & 10.6 & 12.2 & 12.9 & 13.6 \\
\hline Available K $\left(\mathrm{kg} \mathrm{ha}^{-1}\right)$ & 434 & 411 & 434 & 439 & 446 \\
\hline Available S $\left(\mathrm{mg} \mathrm{kg}^{-1}\right)$ & 7.09 & 6.89 & 7.68 & 7.96 & 8.42 \\
\hline DTPA- Zn $\left(\mathrm{mg} \mathrm{kg}^{-1}\right)$ & 1.54 & 1.49 & 1.53 & 1.75 & 1.48 \\
\hline DTPA- Fe $\left(\mathrm{mg} \mathrm{kg}^{-1}\right)$ & 30.5 & 29.8 & 29.2 & 32.2 & 28.3 \\
\hline DTPA-Mn $\left(\mathrm{mg} \mathrm{kg}^{-1}\right)$ & 33.6 & 31.2 & 31.0 & 30.8 & 30.7 \\
\hline DTPA-Cu $\left(\mathrm{mg} \mathrm{kg}^{-1}\right)$ & 6.56 & 6.37 & 6.23 & 6.19 & 6.49 \\
\hline
\end{tabular}

Values are mean of the ten farmers' field data

\section{Soil quality improvement}

The mean RSQI value had improved from $61.8 \%$ to $66.5 \%$ in IPNS, $65.9 \%$ in STNM, $62.8 \%$ in RDF. Whereas in farmers practice the soil quality was deteriorated (RSQI=63.7\%) (Table 4). It was clear that IPNS, STNM and RDF improved the soil quality status of farmers' field, whereas in FP, soil quality was deteriorated when compared to initial soil quality status. Poor soil organic carbon and nutrient deficiencies particularly $\mathrm{N}, \mathrm{S}$, and $\mathrm{P}$ are the major indicators that constraint soil quality in this region.

Table 4: Changes in soil quality status under various management interventions

\begin{tabular}{|c|c|c|c|c|c|c|}
\hline \multirow{3}{*}{ Farmer } & \multirow{2}{*}{ Village } & \multicolumn{5}{|c|}{ RSQI (\%) } \\
\cline { 3 - 7 } & & \multirow{2}{*}{ Initial } & \multicolumn{3}{|c|}{ Final (after two years) } \\
\cline { 3 - 6 } & & & FP & RDF & IPNS & STNM \\
\hline $\mathrm{F}_{1}$ & Chotaguda & 53.8 & 53.8 & 53.8 & 62.5 & 62.5 \\
\hline $\mathrm{F}_{2}$ & Dilawra & 58.8 & 52.5 & 58.8 & 62.5 & 61.3 \\
\hline $\mathrm{F}_{3}$ & Bawdi Kurd & 67.5 & 61.3 & 67.5 & 70.0 & 72.5 \\
\hline $\mathrm{F}_{4}$ & Bhaglawat & 67.5 & 66.3 & 70.0 & 70.0 & 70.0 \\
\hline $\mathrm{F}_{5}$ & Dilawra & 76.3 & 63.8 & 76.3 & 76.3 & 76.3 \\
\hline $\mathrm{F}_{6}$ & Rodudah & 51.3 & 51.3 & 51.3 & 57.5 & 51.3 \\
\hline $\mathrm{F}_{7}$ & Chotaguda & 58.8 & 61.3 & 61.3 & 67.5 & 67.5 \\
\hline $\mathrm{F}_{8}$ & Bhaglawat & 67.5 & 60.0 & 70.0 & 70.0 & 70.0 \\
\hline $\mathrm{F}_{9}$ & Bawdi Kurd & 55.0 & 55.0 & 55.0 & 53.8 & 55.0 \\
\hline $\mathrm{F}_{10}$ & Rodudah & 61.3 & 57.5 & 63.8 & 75.0 & 72.5 \\
\hline Mean & & 61.8 & 58.3 & 62.8 & 66.5 & 65.9 \\
\hline
\end{tabular}

\section{Economics}

Expenses incurred, income generated, and net gain obtained in various management interventions was depicted in Table 5. It was found that the excess cost incurred (Rs. ha ${ }^{-1}$ ) in RDF, IPNS and STNM were 1533, 1719 and 2347 for soybean; 1922, 1936 and 2632 for maize and wheat, respectively over FP. The excess income generated (Rs. ha-1) in the corresponding treatments over FP were 2383, 2943 and 3655 for soybean, 2072, 2113 and 3096 for maize and 2871, 3121 and 5301 for wheat, respectively. Therefore farmers could get higher excess net gain (Rs. ha ${ }^{-1}$ ) of 1308,464 and 2669 by growing soybean, maize and wheat, respectively by adopting STNM. Similarly the excess net gains were (Rs. ha-1) 1224, 177 and 1185 for IPNS and 850, 150, and 949 for RDF practices in these crops (Table 5).

Table 5: Excess cost incurred, excess income generated and net gain due to management interventions

\begin{tabular}{|c|c|c|c|c|c|c|c|c|c|c|c|c|c|c|c|}
\hline \multirow[t]{2}{*}{ Practices } & \multicolumn{3}{|c|}{$\begin{array}{c}\text { Cost of fertilizers and manures } \\
\left(\text { Rs.ha }^{-1}\right)\end{array}$} & \multicolumn{3}{|c|}{$\begin{array}{c}\text { Income } \\
\left(\text { Rs.hat }^{-1}\right)\end{array}$} & \multicolumn{3}{|c|}{$\begin{array}{c}\text { Excess Cost incurred over FP } \\
\left(\text { Rs.ha }^{-1}\right)\end{array}$} & \multicolumn{3}{|c|}{$\begin{array}{c}\text { Excess income over FP } \\
\left(\text { Rs.ha }^{-1}\right)\end{array}$} & \multicolumn{3}{|c|}{$\begin{array}{l}\text { Net gain } \\
\left(\text { Rs.ha }^{-1}\right)\end{array}$} \\
\hline & $\mathbf{S}$ & M & W & $\mathbf{S}$ & M & $\mathbf{W}$ & $\mathbf{S}$ & $\mathbf{M}$ & W & $\mathbf{S}$ & M & $\mathbf{W}$ & $\mathbf{S}$ & $\mathbf{M}$ & W \\
\hline FP & 1723 & & 2024 & 39893 & 27150 & 43461 & - & - & - & - & - & - & - & - & - \\
\hline RDF & 3 & & & 42275 & 29222 & 46332 & 1533 & 1922 & 1922 & 2383 & 2072 & 2871 & 850 & 150 & 949 \\
\hline IPNS & & & & 42835 & 29263 & 46582 & & & & & & 3121 & 1224 & 177 & 1185 \\
\hline STNM & 4070 & 4656 & 4656 & 43548 & 30246 & 48762 & 2347 & 2632 & 2632 & 3655 & 3096 & 5301 & 1308 & 464 & 2669 \\
\hline
\end{tabular}

S-Soybean; M-Maize; W-Wheat

\section{Discussion}

Fertility status of the soils is low particularly in case of OC, $\mathrm{N}, \mathrm{S}$ and P. Soil quality of the region is also found to be very poor. The poor soil fertility and soil quality of the study area are due to low soil organic carbon, excessive nutrient mining, soil erosion, etc. The low soil organic carbon in these soils are because of higher temperatures and poor management practices such as inadequate and imbalanced supply of manures and fertilizers, poor soil and water conservation practices, mono-cropping for a longer period. Similar results are reported by many workers that high temperature in summer might have led to loss of soil organic matter and depletion of soil organic carbon because of imbalance nutrient management ${ }^{[18]}$. Further nutrient mining is found to be higher in imbalanced fertilizer treatments than balanced fertilizers applied treatments ${ }^{[23,24,27]}$. The field experiments across ten 
farmers' fields in the region disclose that improved management practices like STNM and IPNS have improved the crop yield, farmers' income and soil quality. All management interventions have showed better crop yield compared to FP. The STNM treatment has edged over other practices. This is followed by IPNS and RDF. This is due to adequate need based balance supply of nutrients in STNM and reduction of nutrient loss, enhanced and prolonged nutrient availability along with organic matter induced microbial activity in IPNS. Similarly, IPNS and balanced fertilization practices are found to be sustained the different agricultural production systems ${ }^{[20,21,28,30]}$. Integrated nutrient management, balanced nutrient use with high nutrient use efficiency, choice of cropping system, green manuring, etc are technological options for improving soil $\mathrm{C}$ buildup in India [18]. Further soil quality improved due to management practices are in the order of IPNS $>$ STNM $>$ RDF. The higher soil quality enhancement in improved management practices are results of high organic $\mathrm{C}$ and available nutrients particularly $\mathrm{S}$ and $\mathrm{P}$ due to addition of organic matter and balanced fertilization. Whereas in FP soil quality has degraded because of depletion of organic carbon and excess nutrient mining due to inadequate supply on manures and fertilizers. The soil properties like OC, $\mathrm{P}$ and $\mathrm{S}$ has improved in IPNS treatments as a result of addition of FYM and balanced fertilizers. Similarly in STNM also these parameters increased owing to adequate application of deficient nutrients. Further soil quality also has enhanced in these practices. Though the changes are not much in long run it will be beneficial. Moreover the soils in the study area have shallow depth and are prone to erosion because of undulating topography and poor management practices. Major soil texture found in these districts are sandy loam which is reported to be poor in water holding capacity and are conducive to loss of applied fertilizers by leaching process than other textural classes such as loam, clay loam, sandy clay loam, clay, etc ${ }^{[13,26]}$. Therefore soil and water conservation practices along with the nutrient management intervention will be of more advantageous in sustaining crop production in the region.

Table S1: Soybean and Maize yield during kharif 2014-15

\begin{tabular}{|c|c|c|c|c|c|c|}
\hline Farmer & Village & Variety & FP (kg/plot) & RDF (kg/plot) & IPNS (kg/plot) & STNM (kg/plot) \\
\hline Soybean & & & & & & \\
\hline$F_{1}$ & Chotaguda & JS 9560 & 13.5 & 14.0 & 14.3 & 14.5 \\
\hline $\mathrm{F}_{2}$ & Dilawra & JS 9560 & 12.9 & 13.5 & 13.8 & 14.0 \\
\hline $\mathrm{F}_{3}$ & Bawdi Kurd & JS 9560 & 11.9 & 12.5 & 12.6 & 12.8 \\
\hline $\mathrm{F}_{4}$ & Bhaglawat & JS 9560 & 13.1 & 13.9 & 14.0 & 14.1 \\
\hline $\mathrm{F}_{5}$ & Dilawra & JS 9560 & 14.1 & 14.6 & 14.9 & 15.1 \\
\hline $\mathrm{F}_{6}$ & Rodudah & JS 9560 & 12.4 & 12.1 & 13.0 & 13.2 \\
\hline \multicolumn{7}{|l|}{ Maize } \\
\hline $\mathrm{F}_{7}$ & Chotaguda & PEHM 2 & 20.1 & 21.9 & 22.1 & 22.7 \\
\hline $\mathrm{F}_{8}$ & Bhaglawat & PEHM 2 & 16.3 & 17.4 & 17.2 & 17.9 \\
\hline $\mathrm{F}_{9}$ & Bawdi Kurd & PEHM 2 & 15.0 & 15.8 & 16.0 & 16.7 \\
\hline $\mathrm{F}_{10}$ & Rodudah & PEHM 2 & 18.4 & 19.3 & 19.3 & 19.7 \\
\hline
\end{tabular}

Table S2: Wheat yield during rabi 2014-15

\begin{tabular}{|c|c|c|c|c|c|c|}
\hline Farmer & Village & Variety & FP (kg/plot) & RDF (kg/ plot) & IPNS (kg/plot) & STNM (kg/plot) \\
\hline $\mathrm{F}_{1}$ & Chotaguda & GW 322 & 24.7 & 26.9 & 27.1 & 28.4 \\
\hline $\mathrm{F}_{2}$ & Dilawra & GW 322 & 21.3 & 23.4 & 23.7 & 24.5 \\
\hline $\mathrm{F}_{3}$ & Bawdi Kurd & GW 322 & 20.9 & 21.8 & 22.0 & 23.1 \\
\hline $\mathrm{F}_{1}$ & Bhaglawat & GW 322 & 21.1 & 22.8 & 23.0 & 23.9 \\
\hline $\mathrm{F}_{5}$ & Dilawra & GW 322 & 26.0 & 27.4 & 27.8 & 28.9 \\
\hline $\mathrm{F}_{6}$ & Rodudah & GW 322 & 21.6 & 22.7 & 22.9 & 24.2 \\
\hline $\mathrm{F}_{7}$ & Chotaguda & GW 322 & 27.2 & 28.6 & 29.1 & 30.3 \\
\hline $\mathrm{F}_{8}$ & Bhaglawat & GW 322 & 24.5 & 25.3 & 25.9 & 26.4 \\
\hline $\mathrm{F}_{9}$ & Bawdi Kurd & GW 322 & 22.8 & 23.9 & 24.3 & 25.3 \\
\hline $\mathrm{F}_{10}$ & Rodudah & GW 322 & 25.3 & 27.3 & 27.2 & 28.1 \\
\hline
\end{tabular}

Table S3: Soybean/Maize yield during kharif 2015-16

\begin{tabular}{|c|c|c|c|c|c|c|}
\hline Name & Village & Variety & FP (kg/plot) & RDF (kg/plot) & IPNS (kg/plot) & STNM (kg/plot) \\
\hline \multicolumn{7}{|c|}{ Soybean } \\
\hline$F_{1}$ & Chotaguda & JS 9560 & 14.7 & 15.8 & 16.1 & 16.6 \\
\hline$F_{2}$ & Dilawra & JS 9560 & 13.2 & 15.0 & 15.4 & 15.6 \\
\hline$F_{3}$ & Bawdi Kurd & JS 9560 & 11.6 & 12.4 & 12.6 & 12.9 \\
\hline$F_{4}$ & Bhaglawat & JS 9560 & 12.3 & 13.5 & 13.5 & 13.8 \\
\hline$F_{5}$ & Dilawra & JS 9560 & 15.1 & 16.0 & 16.0 & 16.1 \\
\hline$F_{6}$ & Rodudah & JS 9560 & 14.2 & 15.2 & 15.3 & 15.6 \\
\hline \multicolumn{7}{|l|}{ Maize } \\
\hline$F_{7}$ & Chotaguda & PEHM 2 & 22.4 & 24.4 & 24.4 & 25.3 \\
\hline$F_{8}$ & Bhaglawat & PEHM 2 & 17.1 & 19.0 & 18.9 & 19.2 \\
\hline$F_{9}$ & Bawdi Kurd & PEHM 2 & 15.5 & 16.8 & 16.9 & 17.5 \\
\hline$F_{10}$ & Rodudah & PEHM 2 & 20.1 & 21.3 & 21.3 & 22.3 \\
\hline
\end{tabular}


Table S4: Wheat yield during rabi 2015-16

\begin{tabular}{|c|c|c|c|c|c|c|}
\hline Name & Village & Variety & FP (kg/plot) & RDF (kg/ plot) & IPNS (kg/plot) & STNM (kg/plot) \\
\hline$F_{1}$ & Chotaguda & GW 322 & 27.5 & 29.8 & 29.7 & 31.1 \\
\hline$F_{2}$ & Dilawra & GW 322 & 23.0 & 24.5 & 24.7 & 27.1 \\
\hline$F_{3}$ & Bawdi Kurd & GW 322 & 22.9 & 24.3 & 24.5 & 26.1 \\
\hline$F_{1}$ & Bhaglawat & GW 322 & 22.4 & 23.9 & 23.8 & 25.2 \\
\hline$F_{5}$ & Dilawra & GW 322 & 26.4 & 27.8 & 28.1 & 29.2 \\
\hline$F_{6}$ & Rodudah & GW 322 & 22.1 & 23.5 & 23.6 & 24.6 \\
\hline$F_{7}$ & Chotaguda & GW 322 & 26.7 & 28.5 & 28.9 & 2.6 \\
\hline$F_{8}$ & Bhaglawat & GW 322 & 23.6 & 25.1 & 26.0 & 26.1 \\
\hline$F_{9}$ & Bawdi Kurd & GW 322 & 24.5 & 26.8 & 3 & 2.6 \\
\hline$F_{10}$ & Rodudah & GW 322 & 28.4 & 30.5 & 30.0 & \\
\hline
\end{tabular}

Table S5: Changes in Soil pH, OC and mineralizable N

\begin{tabular}{|c|c|c|c|c|c|c|c|c|c|c|c|c|c|c|c|}
\hline \multirow[t]{2}{*}{ Farmers } & \multicolumn{5}{|c|}{ pH } & \multicolumn{5}{|c|}{ OC (\%) } & \multicolumn{5}{|c|}{ Available N $\left(\mathrm{kg} \mathrm{ha}^{-1}\right)$} \\
\hline & Initial & FP & RDF & IPNS & STNM & Initial & FP & RDF & IPNS & STNM & Initial & FP & RDF & IPNS & STNM \\
\hline $\mathrm{F}_{1}$ & 6.6 & 6.8 & 6.9 & 6.7 & 7.1 & 0.33 & 0.35 & 0.46 & 0.54 & 0.52 & 165 & 178 & 189 & 198 & 207 \\
\hline $\mathrm{F}_{2}$ & 7.1 & 7.1 & 6.9 & 7.0 & 7.2 & 0.52 & 0.48 & 0.54 & 0.61 & 0.57 & 208 & 197 & 204 & 215 & 235 \\
\hline $\mathrm{F}_{3}$ & 7.5 & 7.3 & 7.1 & 6.9 & 7.1 & 0.78 & 0.75 & 0.78 & 0.80 & 0.80 & 227 & 221 & 223 & 225 & 233 \\
\hline$F_{1}$ & 6.3 & 6.7 & 7.1 & 6.8 & 7.2 & 0.85 & 0.77 & 0.80 & 0.85 & 0.84 & 289 & 254 & 278 & 293 & 289 \\
\hline $\mathrm{F}_{5}$ & 6.6 & 7.1 & 7.3 & 6.9 & 7.1 & 0.82 & 0.70 & 0.75 & 0.81 & 0.80 & 305 & 286 & 303 & 310 & 322 \\
\hline $\mathrm{F}_{6}$ & 7.8 & 8.1 & 8.0 & 7.5 & 8.2 & 0.42 & 0.44 & 0.46 & 0.52 & 0.51 & 231 & 234 & 245 & 261 & 263 \\
\hline $\mathrm{F}_{7}$ & 6.3 & 6.5 & 6.8 & 6.3 & 7.1 & 0.61 & 0.59 & 0.61 & 0.65 & 0.64 & 272 & 251 & 270 & 283 & 291 \\
\hline $\mathrm{F}_{8}$ & 6.3 & 6.6 & 6.8 & 6.5 & 6.9 & 0.79 & 0.70 & 0.74 & 0.79 & 0.78 & 294 & 267 & 281 & 293 & 295 \\
\hline $\mathrm{F}_{9}$ & 7.3 & 7.1 & 7.3 & 6.9 & 7.4 & 0.22 & 0.29 & 0.33 & 0.42 & 0.39 & 147 & 159 & 167 & 188 & 179 \\
\hline $\mathrm{F}_{10}$ & 7.8 & 7.9 & 7.5 & 7.5 & 7.6 & 0.74 & 0.72 & 0.72 & 0.79 & 0.76 & 282 & 277 & 286 & 301 & 294 \\
\hline
\end{tabular}

Table S6: Changes in Available $\mathrm{P}, \mathrm{K}$ and $\mathrm{S}$

\begin{tabular}{|c|c|c|c|c|c|c|c|c|c|c|c|c|c|c|c|}
\hline \multirow[t]{2}{*}{ Farmers } & \multicolumn{5}{|c|}{$\mathbf{P}$} & \multicolumn{5}{|c|}{$\mathbf{K}$} & \multicolumn{5}{|c|}{$\mathbf{S}$} \\
\hline & Initial & FP & RDF & IPNS & STNM & Initial & FP & RDF & IPNS & STNM & Initial & FP & RDF & IPNS & STNM \\
\hline$F_{1}$ & 12.1 & 12.9 & 14.5 & 16.1 & 15.6 & 222 & 209 & 235 & 230 & 247 & 4.75 & 4.93 & 5.95 & 6.23 & 7.01 \\
\hline $\mathrm{F}_{2}$ & 7.61 & 9.12 & 10.2 & 10.8 & 11.2 & 350 & 319 & 345 & 351 & 354 & 8.65 & 8.02 & 9.31 & 9.45 & 9.91 \\
\hline $\mathrm{F}_{3}$ & 11.6 & 13.4 & 14.6 & 15.2 & 16.1 & 263 & 250 & 272 & 276 & 280 & 4.29 & 4.36 & 4.92 & 5.01 & 5.50 \\
\hline$F_{1}$ & 4.18 & 6.31 & 9.40 & 9.63 & 9.81 & 364 & 347 & 369 & 365 & 372 & 4.53 & 5.01 & 6.03 & 6.19 & 6.22 \\
\hline $\mathrm{F}_{5}$ & 10.7 & 9.74 & 11.4 & 12.5 & 14.4 & 468 & 451 & 460 & 471 & 471 & 10.4 & 9.45 & 10.2 & 10.9 & 11.4 \\
\hline $\mathrm{F}_{6}$ & 12.1 & 12.4 & 13.9 & 13.9 & 14.7 & 378 & 354 & 391 & 389 & 397 & 9.43 & 9.01 & 10.1 & 10.4 & 10.9 \\
\hline $\mathrm{F}_{7}$ & 6.58 & 8.43 & 8.95 & 10.1 & 10.9 & 830 & 762 & 805 & 821 & 839 & 8.21 & 8.19 & 8.95 & 9.25 & 9.55 \\
\hline $\mathrm{F}_{8}$ & 12.1 & 12.1 & 13.6 & 14.1 & 14.5 & 245 & 236 & 246 & 254 & 255 & 5.50 & 5.01 & 5.50 & 5.78 & 6.31 \\
\hline $\mathrm{F}_{9}$ & 11.6 & 12.9 & 13.4 & 14.0 & 14.6 & 441 & 425 & 449 & 453 & 458 & 5.38 & 5.20 & 5.61 & 5.69 & 6.30 \\
\hline $\mathrm{F}_{10}$ & 8.53 & 8.32 & 10.2 & 12.4 & 13.9 & 780 & 753 & 772 & 781 & 785 & 9.75 & 9.71 & 10.2 & 10.7 & 11.1 \\
\hline
\end{tabular}

Table S7: Changes in DTPA-extractable micronutrients

\begin{tabular}{|c|c|c|c|c|c|c|c|c|c|c|c|c|c|c|c|c|c|c|c|c|}
\hline \multirow{2}{*}{ Farmers } & \multicolumn{5}{|c|}{$\mathbf{Z n}$} & \multicolumn{5}{|c|}{\begin{tabular}{|c|}
$\mathrm{Cu}$ \\
\end{tabular}} & \multicolumn{5}{|c|}{$\mathbf{F e}$} & \multicolumn{5}{|c|}{\begin{tabular}{l|l} 
& Mn \\
\end{tabular}} \\
\hline & Initial & FP & RDF & IPNS & STNM & Initial & FP & RDF & IPNS & STNM & Initial & FP & RDF & IPNS & STNM & Initial & FP & RDF & IPNS & STNM \\
\hline$F_{1}$ & 1.52 & 1.40 & 1.61 & 1.63 & 1.57 & 7.81 & 6.45 & 6.73 & 7.12 & 6.80 & 40.3 & 39.9 & 39.0 & 45.1 & 38.5 & 43.5 & 37.1 & 41.8 & 42.9 & 41.0 \\
\hline $\mathrm{F}_{2}$ & 0.91 & 0.83 & 0.90 & 1.03 & 0.87 & 6.05 & 6.19 & 6.09 & 5.95 & 6.11 & 20.3 & 19.7 & 18.4 & 22.1 & 18.7 & 23.5 & 25.1 & 22.8 & 21.0 & 22.3 \\
\hline $\mathrm{F}_{3}$ & 2.42 & 2.33 & 2.40 & 2.69 & 2.23 & 4.77 & 4.68 & 5.11 & 4.57 & 5.04 & 28.3 & 28.9 & 30.1 & 33.0 & 27.9 & 22.6 & 18.3 & 16.4 & 19.9 & 17.8 \\
\hline $\mathrm{F}_{1}$ & 1.13 & 1.17 & 1.14 & 1.34 & 1.10 & 11.2 & 10.1 & 9.44 & 10.9 & 9.89 & 42.7 & \begin{tabular}{|l|}
43.1 \\
\end{tabular} & 42.1 & 44.3 & 42.3 & 51.2 & 45.9 & 44.1 & 40.9 & 43.8 \\
\hline $\mathrm{F}_{5}$ & 2.05 & 1.93 & 2.11 & 2.43 & 2.01 & 9.87 & 9.49 & 10.1 & 9.23 & 10.7 & 45.2 & \begin{tabular}{|l|}
42.0 \\
\end{tabular} & 41.0 & 43.1 & 39.1 & 38.4 & 37.0 & 36.7 & 34.4 & 35.2 \\
\hline $\mathrm{F}_{6}$ & 0.82 & 0.84 & 0.80 & 1.11 & 0.72 & 0.82 & 0.97 & 0.85 & 1.12 & 0.87 & 12.3 & 12.0 & 12.2 & 13.8 & 12.5 & 18.4 & 19.1 & 17.5 & 18.2 & 17.1 \\
\hline $\mathrm{F}_{7}$ & 2.72 & 2.64 & 2.68 & 2.98 & 2.62 & 8.76 & 8.59 & 8.54 & 7.92 & 8.74 & 31.7 & 33.5 & 29.2 & 32.6 & 29.9 & 48.5 & \begin{tabular}{|l|}
44.9 \\
\end{tabular} & 45.7 & 42.7 & 44.0 \\
\hline $\mathrm{F}_{8}$ & 1.64 & 1.63 & 1.60 & 1.65 & 1.58 & 10.4 & 11.2 & 9.93 & 9.67 & 10.9 & 50.7 & \begin{tabular}{|l|}
47.1 \\
\end{tabular} & 48.0 & 49.2 & 44.1 & 46.3 & 41.2 & 42.0 & 44.5 & 43.6 \\
\hline $\mathrm{F}_{9}$ & 0.61 & \begin{tabular}{|l|}
0.59 \\
\end{tabular} & 0.57 & 0.97 & 0.57 & 2.11 & 2.17 & 2.04 & 1.99 & 2.08 & 21.1 & \begin{tabular}{|l|}
19.8 \\
\end{tabular} & 20.2 & 25.7 & 18.9 & 15.0 & 14.3 & 15.2 & 14.7 & 14.1 \\
\hline$F_{10}$ & 1.56 & 1.54 & 1.50 & 1.69 & 1.49 & 3.83 & 3.88 & 3.45 & 3.40 & 3.72 & 12.8 & 12.0 & 11.8 & 13.4 & 11.3 & 28.9 & 29.4 & 28.0 & 28.5 & 27.6 \\
\hline
\end{tabular}

\section{Conclusions}

From the study it is apparent that the soils in the region are deficient in many numbers of available nutrients and have poor soil quality status. Further they are prone to soil erosion due to shallow soil depth, undulating topography and poor management practices. Introduction of improved management interventions like IPNS and STNM have enhanced crop yield, farmers' income and quality of soil. Therefore it is recommended that adoption of improved management practices such as IPNS and STNM in the region could sustain the production system. Moreover impact of long term adoption of soil and water conservation along with these management practices on soil quality and crop productivity in these regions will give more understanding of the subject which is beyond the scope of the current investigation.

\section{Acknowledgement}

The authors are thankful to Staff of Madhya Pradesh State Department of Farmers Welfare and Agricultural Development; and KVK, Dhar and KVK, Jhabua for their valuable support during field experimentation in the farmers' fields. 


\section{References}

1. Alagh YK, Kashyap SP, Murthy GVSN. Agro- climatic Regional Planning: An over view. Planning Commission, New Delhi, 1989.

2. Andrews SS, Mitchell JP, Mancinelli R, Karlen DL, Hartz TK, Horwath WR et al. On-farm assessment of soil quality in California's Central Valley. Agronomy Journal. 2002; 94:12-23.

3. Dick RP. Soil Enzyme Activity as an Indicator of Soil Quality. In: Doran JW, et al., editors. Defining soil quality for a sustainable environment, Soil Science Society of America, Madison, WI, 1994, 107-124.

4. Doran JW, Jones AJ. Methods for Assessing Soil Quality. Soil Science Society of America Special Publication, vol. 49. Soil Science Society of America, Madison, Wisconsin, 1996.

5. Doran JW, Sarrantonio M, Liebig M. Soil health and sustainability. In: Sparks, DL (Ed), Advances in Agronomy, Vol 56. Academic Press, San Diego, 1996, 154.

6. Doran JW, Zeiss MR. Soil health and sustainability: managing the biotic component of soil quality. Applied Soil Ecology. 2000; 15:3-11.

7. Elliott ET. The potential use of soil biotic activity as an indicator of productivity, sustainability and pollution. In: Pankhurst C, Doube BM, Gupta V (Eds). Soil Biota. Management in Sustainable Farming Systems. CSIRO, Australia, 1994, 250-256.

8. Ghosh SP. Agro-climatic Zone Specific Research India Perspective under NARP. ICAR, New Delhi, 1991, 1539.

9. Granatstein D, Bezdicek DF. The need for a soil quality index: local and regional perspectives. American Journal of Alternative Agriculture. 1992; 7:12-16.

10. Hanway JJ, Heidel H. Soil analysis methods as used in Iowa State College, Soil Testing Laboratory, Iowa State College Bulletin. 1952; 57:1-131.

11. Hatfield JL, Karlen DL. Sustainable Agriculture Systems. CRC press Inc., Boca Raton, Florida, 1993.

12. Hedlund A, Witter E, An BX. Assessment of N, P and K management by nutrient balances and flows on periurban smallholder farms in southern Vietnam. European Journal Agronomy. 2003; 20:71-87.

13. Hillel D. Environmental soil physics. Academic Press, San Diego, CA, 1998.

14. Jackson ML. Soil Chemical Analysis. Prentice Hall of India, New Dehli, 1973.

15. Karlen DL, Andrews SS, Doran JW. Soil quality: Current concepts and applications. Advances in Agronomy. 2001; 74:1-40.

16. Khanna SS. Farm planning: The agro-climatic approach. In: The Hindu- Survey of India Agriculture. The Hindu, Chennai, 1989, 28-35.

17. Lal R, Stewart BA. Soil Management: Experimental Basis for Sustainability and Environmental Quality. Advances in Soil Science, CRC Press, Boca Raton, Florida, 1995.

18. Lal R. Soil carbon sequestration impacts on global climate change and food security. Science 2004; 304:1623-1627.

19. Lindsay WL, Norvell WA. Development of a DTPA soil test for zinc, iron, manganese, and copper. Soil Science Society of America Journal. 1978; 42:421-428.

20. Manna MC, Swarup A, Wanjari RH, Mishra B, Shahi DK. Long-term fertilization, manure and liming effects on soil organic matter and crop yields. Soil Tillage Research. 2007; 94:397-409.

21. Manna MC, Swarup A, Wanjari RH, Ravankar HN, Mishra B, Saha MN et al. Long-term effect of fertilizer and manure application on soil organic carbon storage, soil quality and yield sustainability under sub-humid and semi-arid tropical India. Field Crops Research. 2005; 93:264-280.

22. Olsen SR, Cole CV, Watanabe FS, Dean LA. Estimation of available phosphorus in soils by extraction with sodium bicarbonate. USDA Circular, 1954, 939.

23. Panda D, Samantaray RN, Misra AK, Senapati HK. Nutrient balance in rice. Indian Journal of Fertilizers. 2007; 3:33-38

24. Pathak H, Mohanty S, Jain N, Bhatia A. Nitrogen, phosphorus, and potassium budgets in Indian agriculture. Nutrrient Cycling in Agroecosystem. 2010; 86:287-299.

25. Saha JK, Rajendiran Selladurai, Vassanda Coumar M, Dotaniya ML, Kundu S, Patra AK. Soil Pollution an emerging threat to agriculture. Springer, Singapore, 2017.

26. Saxton KE, Rawls WJ, Romberger JS, Papendick RI. Estimating generalized soil water characteristics from texture. Transactions of the American Society of Agricultural Engineers. 1986; 50:1031-1035.

27. Singh M, Singh VP, Reddy DD. Potassium balance and release kinetics under continuous rice-wheat cropping system in Vertisol. Field Crops Research. 2001; 77:8191.

28. Srinivasarao Ch, Venkateswarlu B, Lal R, Singh AK, Kundu S. Sustainable management of soils of dryland ecosystems of India for enhancing agronomic productivity and sequestering carbon. Advances in Agronomy. 2013; 121:253-329.

29. Subbiah BV, Asija GL. A rapid procedure for estimation of available nitrogen in soils. Current Science. 1956, 25:259-260.

30. Uppal RK, Wani SP, Garg KK, Alagarswamy G. Balanced nutrition increases yield of pearl millet under drought. Field Crops Research. 2015; 177:86-97.

31. Velayutham M, Mandal DK, Mandal C, Sehgal J. Agroecological sub-regions of India for Planning and Development, National Bureau of Soil Survey and Land Use Planning, Nagpur, NBSS Publication No. 35, 1999, $1-372$.

32. Walkley AJ, Black IA. Estimation of soil organic carbon by the chromic acid titration method. Soil Science. 1934; 37:29-38.

33. Wang XJ, Gong ZT. Assessment and analysis of soil quality changes after eleven years of reclamation in subtropical China. Geoderma. 1998; 81:339-355.

34. Williams $\mathrm{CH}$, Steinbergs A. Soil sulphur fractions as chemical indices of available sulphur in some Eastern Australian soils. Australian Journal of Agricultural Research. 1959; 10:340-352. 